\title{
Characterization of Insulin Binding \\ to Isolated Ovine Adipocytes
}

\author{
Shin-ichi SASAKI and Yasukuni WATANABE \\ Faculty of Agriculture, Shinshu University, Minamiminowa-mura, \\ Nagano-ken 399-45
}

(Received August 25, 1985)

\begin{abstract}
To study the mechanism of insulin resistance in ruminant adipose tissues, we measured the binding of insulin to isolated adipocytes obtained from sheep and rats. Our data demonstrated that insulin readily and specifically bound to ovine adipocytes as well as to rat adipocytes. The time course of this reaction indicated that steady state binding conditions remained constant during an incubation period between 1 and 2 hours. The specific binding of ${ }^{125} \mathrm{I}$-insulin to ovine and rat adipocytes was $4.8 \%$ and $6.9 \%$ for $1 \times 10^{6}$ cells, respectively. At concentrations of unlabeled insulin between 3.9 $\times 10^{-11} \mathrm{M}$ and $4.2 \times 10^{-9} \mathrm{M}$ ovine adipocytes showed significantly less specific binding than rat adipocytes. When analyzed by Scatchard plots based on negative cooperativity model, the total receptor concentration $\left(R_{0}\right)$ in ovine adipocytes was identical to that in rat adipocytes, but the affinity of the empty receptor $\left(\bar{K}_{\varepsilon}\right)$ was reduced to about $70 \%$ of that in rat adipocytes. The average affinity profile at occupancy of $10 \%$ of insulin receptors on ovine adipocytes was considerably lower than that of rat adipocytes. These results indicated that a lower insulin binding to adipocytes in sheep was due to conspicuously lower affinity of the receptor for insulin, without any difference of receptor concentration. This may be related to insulin resistance in ruminants.
\end{abstract}

Jpn. J. Zootech. Sci., 57 (6): 503-511, 1986

Key words: insulin resistance, ovine adipocytes, receptor, insulin binding, affinity

It has been reported that adipose tissues from ruminants respond poorly to insulin in vitro ${ }^{1-3)}$ suggesting that ruminant tissues are insulin resistant or insensitive. The mechanism of insulin resistance in ruminants is still unknown, although in non-ruminants it has been shown that insulin insensitivity in a number of different disease states may be due to an impaired ability of insulin binding to receptors ${ }^{4-6)}$.

It is thought that the initial step in insulin action involves binding of insulin to a specific plasma membrane receptors ${ }^{7)}$. In non-ruminants, insulin receptor binding has been well established by the investigations using adipocytes, hepatocytes, lymphocytes and erythrocytes ${ }^{7.8}$. It seems to be important to study insulin-receptor binding in adipocytes which is a major site of insulin action in ruminants as well as non-ruminants. However, insulin binding has been less thoroughly characterized in ruminant adipocytes, due to the difficulty in obtaining biologically active adipocytes ${ }^{9)}$. There are a few reports which indicate that ruminant adipocytes will be useful to study insulin binding ${ }^{10.11)}$, although no quantitative information has been presented. More recently, VAsILATos et al. ${ }^{12}$ ) have reported that the insensitivity to insulin in cattle was associated with a negligible capacity for insulin binding to adipocytes, but it has not 
been clarified whether the lack of insulin-receptor binding might be due to decreased numbers of insulin receptor or decreased affinity for insulin to the receptors.

The aim of the present study is, therefore, to systematically characterize binding of insulin to the specific receptor located on isolated ovine adipocytes and to clarify the mechanism of insulin resistance in ruminants, according to compare insulin-receptor binding in ovine adipocytes with that in rat abipocytes.

\section{Materials and Methods}

\section{Experimental animals}

Four adult female Suffolk $\times$ Corriedale crossbred sheep weighing $33-43 \mathrm{~kg}$ were used. They were housed in individual cages at an environmental temperature of $19-21^{\circ} \mathrm{C}$. They were fed $800 \mathrm{~g}$ of hay cube and $200 \mathrm{~g}$ of concentrate (New calf super pellet; crude protein $21 \%$, crude fat $2 \%$, crude fiber $5 \%$, crude ash $7 \%$, TDN $77 \%$, DCP 19\%, : Nihon Haigo Shiryo Co., Ltd.) once daily at $0800 \mathrm{~h}$, but they were allowed free access to water. Food was generally consumed within $2 \mathrm{~h}$. On the day of experiments, animals were not fed until the end of sampling of blood and adipose tissues. Blood samples were taken at $0800 \mathrm{~h}$ from the jugular vein with heparinized syringes. Plasma was separated by centrifugation and stored at $-40^{\circ} \mathrm{C}$ until the assay of insulin and glucose.

Female Wistar strain rats weighing $190 \mathrm{~g}, 10$ weeks of age, were used and fed Oriental rat chow (Oriental Yeast Co., Ltd.). Water was available continuously. Rats were decapitated immediately after a blow to the head between $0800-0900 \mathrm{~h}$. Blood from the cervical stump was drained into a heparinized test tube.

Isolation of adipocytes

Ovine adipose tissues (3-4 g) were obtained by open biopsy from the rump region after an incisal area was locally anesthetized with $2 \%$ procaine hydrochloride. Subcutaneous adipose tissues were taken out and immediately placed in $0.154 \mathrm{M} \mathrm{NaCl}$ $\left(38^{\circ} \mathrm{C}\right)$. Adipose tissues were then rinsed with fresh saline and dissected free of connective tissues and blood vessels. Isolated adipocytes were prepared according to modification of the method of RoDBELL ${ }^{13)}$. Briefly, the tissue weighing approximately

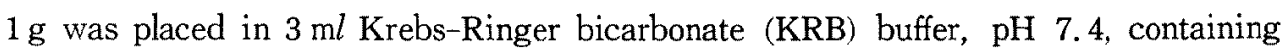
$1 \mathrm{mg} / \mathrm{m} l$ collagenase (Type II; Sigma Chemical Co. ), $1.1 \mathrm{mM}$ glucose and $3.5 \%$ BSA (Fraction V; Sigma Chemical Co.) in $20-\mathrm{m} l$ siliconized vials. The tissues were then minced, gassed for $3 \mathrm{~min}$ with $95 \% \mathrm{O}_{2}-5 \% \mathrm{CO}_{2}$, and incubated at $37^{\circ} \mathrm{C}$ for 2.5 hours, swirling gently every $30 \mathrm{~min}$ without continuous shaking. After collagenase digestion, isolated cells were filtered through $177 \mu \mathrm{m}$ nylon mesh, centrifuged at $400 \times \mathrm{g}$ for 40 sec, and washed three times with warm KRB buffer containing $2 \% \mathrm{BSA}$, after which the cells were suspended in $35 \mathrm{mM}$ Tris buffer ( $\mathrm{pH} \mathrm{7.6)}$.

Rats were killed by decapitation and the parametrial adipose tissues were removed, and isolated adipocytes were prepared by the method of RoDBELL ${ }^{13}$.

The cell number was directly counted and the cell size was measured on Burker Turk haemocytometer with a calibrated microscope by the method of Di Girolamo 
et al. ${ }^{14)}$ With this procedure, the yield of cells approximately $2.6 \times 10^{6} / \mathrm{g}$ fresh tissue and $1 \times 10^{7}$ cells/g fresh tissue in sheep and rats, respectively. There was no significant difference in average diameter of isolated adipocytes $(45-65 \mu \mathrm{m})$ between sheep and rats.

\section{Binding studies}

Isolated fat cells were suspended in the buffer containing $35 \mathrm{mM}$ Tris, $120 \mathrm{mM}$ $\mathrm{NaCl}, 1.2 \mathrm{mM} \mathrm{MgSO}$, $2.5 \mathrm{mM} \mathrm{KCl}, 10 \mathrm{mM}$ glucose, $2.0 \mathrm{mM} \mathrm{CaCl}_{2}$, and $2 \%$ bovine serum albumin, $\mathrm{pH} 7.6$, and incubated with $0.05 \mathrm{nM}{ }^{125} \mathrm{I}$-insulin (porcine insulin, specific activity; $200 \mu \mathrm{Ci} / \mu \mathrm{g}$, Dainabot RI Lab. Ltd.) and various concentrations of unlabeled insulin (porcine mono-component insulin; Novo Industri). Incubations were performed in polyethylene tubes (Eiken RIA tube 2) at $24^{\circ} \mathrm{C}$ for $60 \mathrm{~min}$ in a shaking water bath. After the incubations were terminated, an aliquot of $200 \mu \mathrm{l}$ of cell suspension was rapidly centrifuged in plastic microcentrifuge tubes (Eppendorf) containing $100 \mu$ dinonyl phthalate as described by Gammeltoft and GlimmanN ${ }^{15)}$. Dinonyl phthalate has a specific gravity intermediate between buffer and cells; therefore, after centrifugation, three layers were separated cells on the top, dinonyl phthalate in the middle, and buffer at the bottom. The tubes were cut with a knife through the dinonyl phthalate layer. The cells were transferred to the counting tubes and the radioactivity of the separated cell was determined with a well-type gamma counter (Aloka ARC-300). Nonspecific binding was assessed by incubating cells with ${ }^{125} \mathrm{I}-$ insulin and $50 \mu \mathrm{g} / \mathrm{m} l$ unlabeled insulin and was subtracted from the total binding to determine the specific binding. Nonspecific binding was $17.2 \%$ of the total binding without any difference between sheep and rats.

\section{Insulin and glucose determinations}

Plasma insulin was measured with a RIA kit (Dainabot RI Lab. Ltd.) using rat (24.7 IU/mg, Eli Lilly Co.) and ovine insulin (24.1 IU/mg, Sigma Chemical Co.) as a standard. Blood glucose was determined by the glucose oxidase method ${ }^{16}$.

Statistics

Statistical analysis of the data was preformed by Student's $t$-test. The level of significance was chosen at $\mathrm{P}<0.05$.

\section{Results}

Blood glucose levels of sheep were lower than that of the rats. There were no significant differences in plasma insulin levels between both species (Table 1).

Figure 1 depicts the time course of specific and nonspecific ${ }^{125} \mathrm{I}$-insulin binding,

Table 1. General observations of the experimental animals

\begin{tabular}{lcc}
\hline & Sheep & Rat \\
\hline Body weight & $37.1 \pm 2.1 \mathrm{~kg}$ & $192.5 \pm 1.4 \mathrm{~g}$ \\
Blood glucose $(\mathrm{mg} / \mathrm{d} l)$ & $41.7 \pm 3.0$ & $95.4 \pm 2.2$ \\
Plasma IRI $(\mathrm{ng} / \mathrm{m} l)$ & $0.95 \pm 0.18$ & $1.18 \pm 0.06$ \\
\hline
\end{tabular}

Mean \pm SE. 
and the effect of cell concentration on ${ }^{125} \mathrm{I}$-insulin binding to isolated ovine adipocytes. The specific binding of ${ }^{125} \mathrm{I}$-insulin to ovine adipocytes occurred rapidly, reaching a peak at about one hour, followed by maintaining the maximal level until at least 2 hours of incubations. The nonspecific binding increased slightly with increasing incubation time (Fig. 1B). ${ }^{225} \mathrm{I}$-insulin specifically bound to ovine adipocytes increased
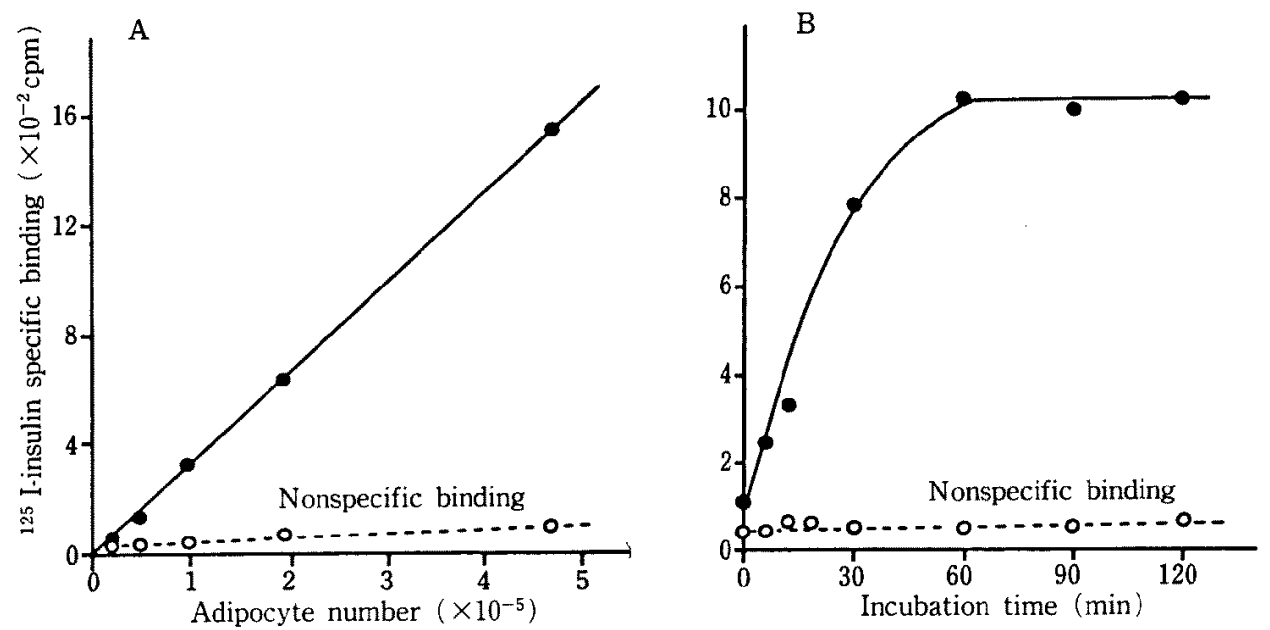

Fig. 1. The effect of cell numbers (A) and incubation time (B) on specific and nonspecific binding of ${ }^{125}$ I-insulin to ovine adipocytes.

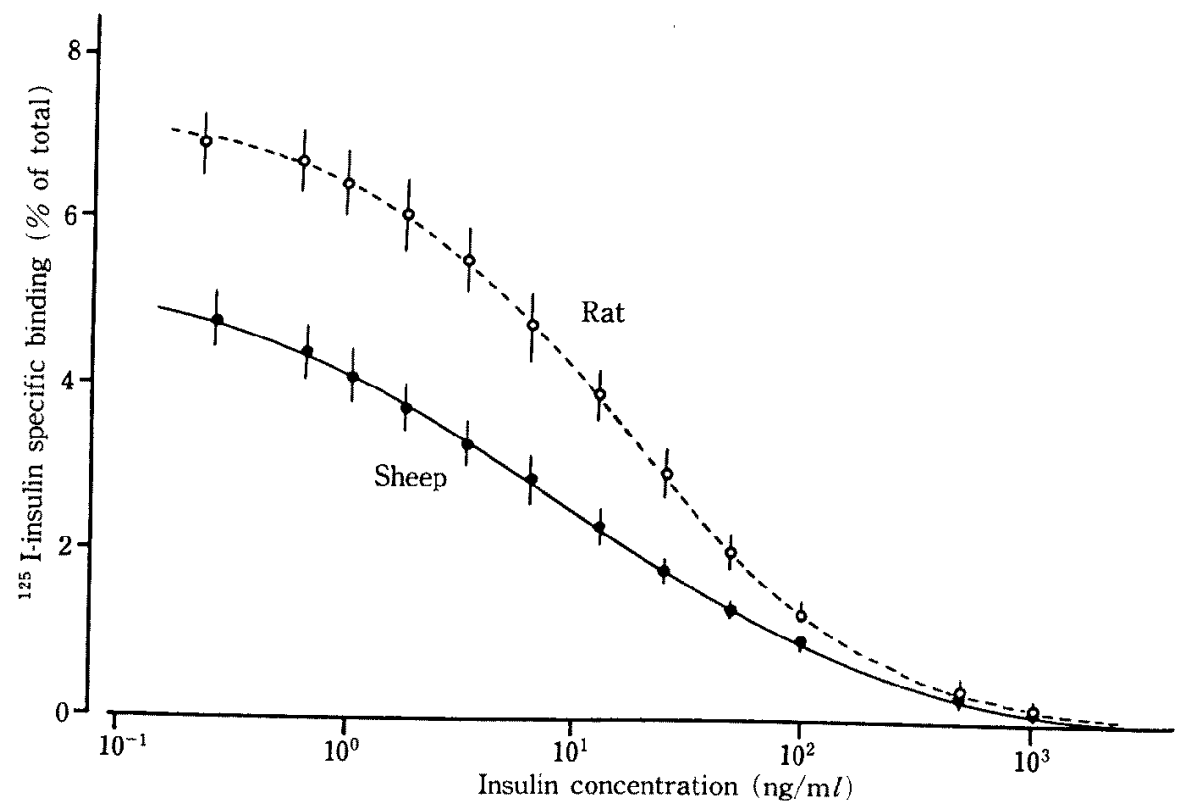

Fig. 2. Specific binding of ${ }^{120} \mathrm{I}$-insulin to ovine $(n=4)$ and rat $(n=5)$ adipocytes. Adipocytes were incubated at $24^{\circ} \mathrm{C}$ for 1 hour with $0.05 \mathrm{nM}{ }^{125} \mathrm{I}$-insulin and different concentrations of native porcine insulin. The results represent the mean \pm S.E. 
Insulin Binding to Isolated Ovine Adipocytes

linearly with increasing the number of adipocytes (Fig. 1A). This linear relationship permits normalization of data among animals where different adipocyte concentrations were prepared.

The displacement curves for insulin binding in sheep and rats are shown in Figure 2. Ovine adipocytes showed a considerably greater decrease in the specific binding of ${ }^{125} \mathrm{I}$-insulin tracer as compared with that in rat adipocytes $(4.82 \pm 0.41 \%$ vs. $6.89 \pm 0.45 \%$ for $1 \times 10^{6}$ cells; $\left.\mathrm{P}<0.02\right)$. At concentrations of unlabeled porcine insulin between $0.23 \mathrm{ng} / \mathrm{ml}$ and $25.2 \mathrm{ng} / \mathrm{ml}$, the insulin binding capacity of ovine adipocytes was also significantly lower than that of rat adipocytes $(\mathrm{P}<0.01-\mathrm{P}<0.02)$, but no significant difference between sheep and rats was found at higher insulin concentrations than $50 \mathrm{ng} / \mathrm{ml}$. On the other hand, the specific binding of ${ }^{125}[$-insulin to both sheep and rat adipocytes could be readily inhibited at physiological concentrations of unlabeled insulin.

The kinetics of insulin-receptor interaction was analyzed using Scatchard plots ${ }^{17}$. As shown in Figure 3, Scatchard plots in both sheep and rats were curvilinear.

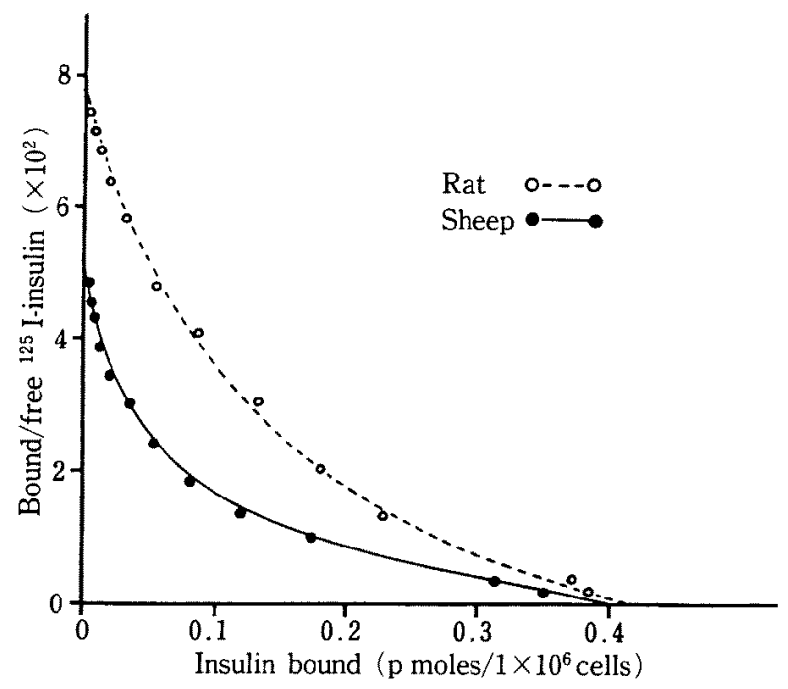

Fig. 3. Scatchard plot of the binding result shown in Figure 2. The values are corrected for the nonspecific binding.

Table 2. Affinity constants and total receptor concentration for adipocytes in sheep and rats

\begin{tabular}{lcc}
\hline & Sheep & Rat \\
\hline $\bar{K}_{e}\left(\times 10^{8} \mathrm{M}^{-1}\right)$ & 1.29 & 1.26 \\
$\bar{K}_{f}\left(\times 10^{8} \mathrm{M}^{-1}\right)$ & 0.50 & 0.67 \\
$R_{o}\left(\times 10^{5}\right.$ sites/cell $)$ & 2.32 & 2.56
\end{tabular}

Scatchard plots shown in Figure 3 were analyzed by the negative cooperativity model according to De Meyts and Roth (1975). $\bar{K}_{e}$ is the affinity of the empty receptor, $\bar{K}_{f}$ is the affinity of the filled receptor, and $R_{o}$ is the total receptor concentration. 


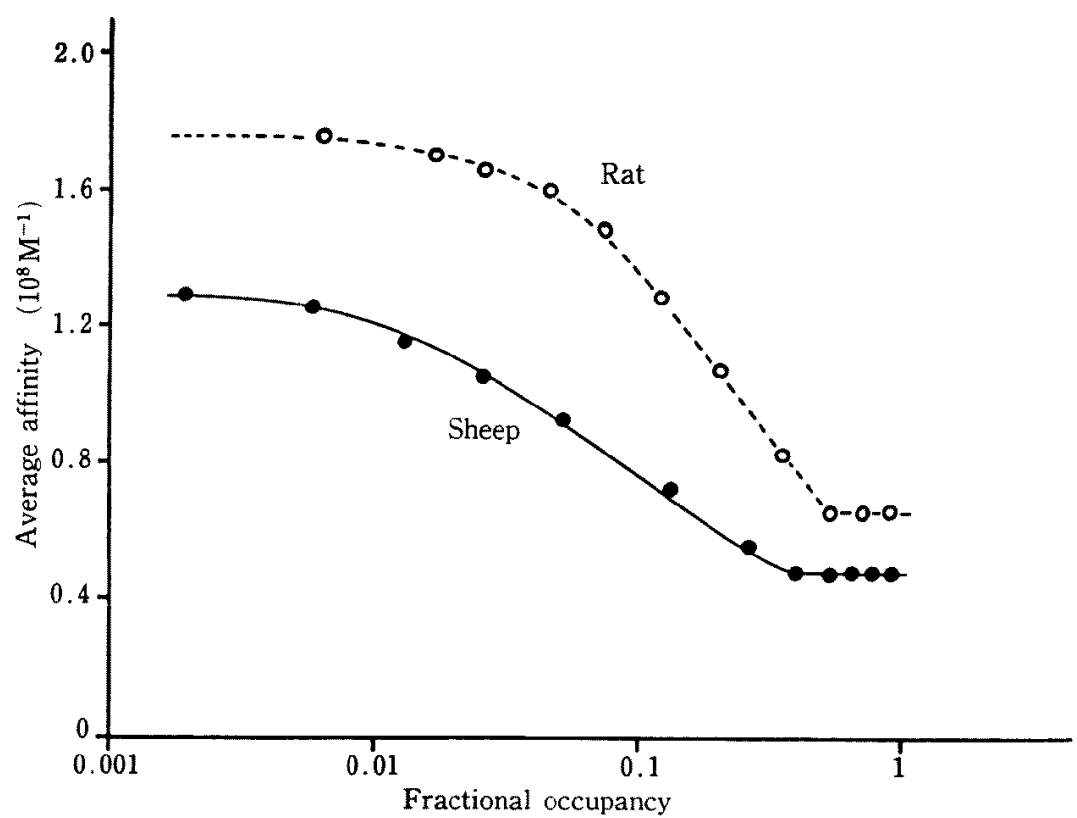

Fig. 4. Average affinity profile for insulin binding to adipocytes estimated from Scatchard plot. The average affinity is calculated as $(B / F) /\left(R_{O}-B\right)$ and is plotted as a function of the log of fractional occupancy $\left(B / R_{O}\right) . \quad B$; insulin bound, $F$; free insulin, $R_{O}$; total insulin receptor concentration.

Therefore, these plots were analyzed based on a negative cooperativity model according to DE MEYTS and RoTH ${ }^{18.19)}$. The affinity of the empty receptor $\left(\bar{K}_{e}\right)$, where receptors are not occupied by insulin, was reduced in ovine adipocytes to about $70 \%$ of that in rat adipocytes. However, both the affinity of the filled receptor $\left(\bar{K}_{f}\right)$ and the total number of binding sites per cell $\left(R_{0}\right)$ were almost identical in sheep and rats (Table 2).

Since the affinity of adjacent receptors to insulin has been suggested to decrease as the receptors being combined with insulin in a stoichiometric (stepwise) manner, we tried to use "average affinity profile"18). Figure 4 illustrates the relationship between the fractional occupancy of receptor and the average affinity. When the comparison of average affinity was made at 10\% occupancy between ovine adipocytes and rat adipocytes, since it has been suggested that maximal biological effect occurs at only $2-10 \%$ of occupancy of insulin receptors ${ }^{6,20,21}$, the average affinity in sheep decreased to $50 \%$ of that in rats. The average affinity profiles for sheep and rats were also not parallel at all levels of occupancy.

\section{Discussion}

It has long been suggested that isolation of adipocytes from ruminant adipose tissues seemed rather difficult, because ruminant adipocytes are extremely fragile ${ }^{22)}$, porbably due to differences in the composition of fatty acids in adipose tissues ${ }^{23)}$ and 
in the amount or hardiness of connective tissues ${ }^{24}$. The results of the present investigation clearly shows that ruminant adipocytes could be isolated by our careful modification in maintaining high temperature $\left(38^{\circ} \mathrm{C}\right)$, avoiding the excess physical treatment such as high speed centrifugation and vigorous shaking during cell preparation. It was also important to pay attention to the selection of collagenase, sinec it is known that the collagenase containing high tryptic activity destroys the insulin receptor. It would be less difficult to isolate physiologically active adipocytes from ovine subcutaneous adipose tissues, using our improved techniques reported herein, which will be useful for further studies in examining hormone binding and action in ruminants.

Since it has been defined that insulin binding to a specific plasma membrane receptor is the first step in a sequence of reaction which leads to the biological responses $^{7}$, the mechanism of insulin resistance in a large number of different disease states has been investigated in relation to the interaction between insulin and its receptor. Insulin resistance in target tissues is accounted by the decreased binding of insulin to its receptor and/or the post receptor coupling defect in insulin action ${ }^{6.26)}$. However, up to now, the mechanism of insulin resistance in ruminants is still unknown. The interaction between insulin binding and insulin action in non-ruminant adipocytes which is the essential target cell of insulin has been well documented; nevertheless, the characteristics of insulin binding to ruminant adipocytes have not been clearly established. In order to clarify the mechanism of insulin resistance in ruminants, we measured insulin binding to isolated ovine adipocytes in comparing with rats.

Our data demonstrated that insulin readily and specifically bound to ovine adipocytes as well as rat adipocytes, but the insulin binding in ovine adipocytes was significantly lower than that in rat adipocytes at physiological concentrations of insulin. Scatchard analysis indicated that the total receptor number in ovine adipocytes was identical to that in rat adipocytes, but $\bar{K}_{e}$ was reduced to about $70 \%$ of that in rat adipocytes. This result suggests that lower insulin binding to ovine adipocytes is due to lower affinity to the receptor rather than the number of receptor. Although precise interpretation of the curvilinear Scatchard plots is difficult, analyses of these curvilinear plots based on negative cooperativity medel were used in this study solely for comparative purposes. An additional possible interpretation would be the presence of heterogeneity of receptors or a combination of negative cooperativity and heterogeneity. Specific differentiations of these latter possibilities could not be easily obtained. VASILATOS et $a l^{12)}$. reported that the specific binding of insulin to bovine adipocytes was negligible, and nonspecific binding was $74 \%$ of the total binding. Their nonspecific binding is extremely higher than our results found in this studies ( $17 \%$ of the total binding). This high nonspecific binding suggests that separation of insulin bound from buffer was incomplete, leading to a relatively lower specific binding.

In this study, the average affinity in sheep was lower than that in rats. Furthermore, average affinity profile showed that a difference in average affinity between sheep and rats became larger in proportion to the decrease in occupancy of receptor. 
It has been suggested that antireceptor antibodies, and counterregulatory hormone such as glucocorticoid and epinephrine are concerned in insulin binding ${ }^{26,27)}$. SASAKI et al. ${ }^{28,29)}$ reported using intact and adrenalectomized sheep that glucocorticoid played an important role in ruminant insulin tolerance, but that epinephrine was less related to insulin tolerance than glucocorticoid. Although it is not known whether insulin resisitance seen in ruminants is due to the direct effect of glucocorticoid on insulin binding site or not, insulin resistance in sheep may be due to, at least in part, a lower insulin binding caused by a lower affinity of the receptor for insulin.

In summary, the present studies have demonstrated and systematically characterized the binding of insulin to isolated ovine adipocytes, and clarified a part of the mechanism of insulin resistance in ruminants by comparing insulin-receptor binding in ovine adipocytes with that in rat adipocytes. It has been also shown that the binding of insulin to its receptor are not necessarily an index in regulation of insulin action in ruminants, as is known in non-ruminants. Further studies that clarify the relationship between insulin binding and the post receptor events are required to elucidate the detailed mechanism of insulin resistance or the role of insulin in ruminats.

\section{References}

1) Baldwin, R. L., J.R. Reichl, S. Louis, N. E. Smith, Y. T. Yang and E. Osborne, J. Dairy Sci. 56: 340-349. 1973 .

2) Vernon, R. G., Int. J. Biochem. 8: 517-523. 1977.

3) Vernon, R. G., Int. J. Biochem. 10:57-60. 1979.

4) Olefsky, J. M., Diabetes 25: 1154-1162. 1976.

5) Bar, R. S., L. C. Harrison and M. Muggo, Adv. Intern. Med. 24: 23-46. 1979.

6) KAHN, C. R., Metabolism 29; 455-465. 1980.

7) KAHN, C. R., J. Cell Biol. 70: 261-286, 1976.

8) FreycheT, P., Diabetologia 12: 83-100. 1976.

9) Etherton, T. D., E. H. Thompson and C. E. Allen, J. Lipid Res. 18: 552-557. 1977.

10) Yang, Y. T. and R. L. Baldwin, J. Dairy Sci. 56: 350-365. 1973.

11) Vernon, R. G., R. A. Clegg and D. J. Flint, Biochem. J. 200: 307-314. 1981.

12) Vasilatos, R., T. D. Etherton and P. J. Wangsness, Endocrinology 112: 1667-1673. 1983.

13) Rodbell, M., J. Biol. Chem. 239: 375-380. 1964.

14) Di Girolamo, M., S. Medlinger and J. W. Fertig, Am. J. Physiol. 221: 850-858. 1971.

15) Gammeltoft, S. and J. Gliemann, Biochim. Biophys. Acta, 320: 16-32. 1973.

16) Huggett, A.S. G. and D. A. Nixon, Lancet 2: 368-370. 1957.

17) Scatchard, G., Ann. N. Y. Acad. Sci. 51: 669-672. 1949.

18) De Meyts, P. and J. Roth, Biochem. Biophys. Res. Commun. 66: 1118-1126. 1975.

19) De Meyts, P., A. R. Biano and J. Roth, J. Biol. Chem. 251: 1877-1888. 1976.

20) Kono, T. and F. W. Barham, J. Biol. Chem. 246: 6210-6216. 1971.

21) Olefsky, J. M., J. Clin. Invest. 57: 842-851. 1976.

22) Vernon, R. G., J. P. Robertson, P. A. Clegg and D. J. Flint, Biochem. J. 196: 819-824. 1981.

23) Williais, J. E., D. G. Waller, L. E. Bulgerin, J. J. Guenther, L. E. Walters, G. W. Horn and G. R. Waller, J. Anim. Sci. (Suppl) 53: 445. 1981. (Abstract)

24) Bulgerin, L. E., J. H. Liao, J. E. Williams, J. J. Guenther, L. E. Walters and D. G. Wagner, J. Anim. Sci. (Suppl) 53: 208. 1981. (Abstract)

25) Kahn, C. R., K. L. Baird, J. S. Fller, C. Grunfeld, J. T. Harmon, L. C. Harrison, F. A. Karlsson, M. Kasuga, G. L. King, U. C. Lang, J. M. Ponskalny and E. V. Obberghen, Res. Prog. Horm. Res. 37: 477-533. 1981. 


\title{
Insulin Binding to Isolated Ovine Adipocytes
}

26) Flier, J. S., C. R. KahN, J. Roth and R. S. Bar, Science 190: 63-65. 1975.

27) Crunfeld, C., K. Baird, E. V. Obeerchen and C. R. Kahn, Endocrinology 109: 1723-1730. 1981 .

28) Sasaki, Y, K. Moriya and H. Hamada, Jpn. J. Zootech. Sci. 52: 780-788. 1981.

29) Moriya, K. and Y. Sasaki, Jpn. J. Zootech. Sci. 55: 562-568. 1984.

\section{めん羊の単離脂肪細胞に対するインスリン結合の特性}

\author{
佐々木晋一・渡辺泰邦
}

信州大学農学部, 長野県南箕輪村 399-45

一般に反䂏動物はインスリンに対して抵抗性あるいは 低感受性であるとされているが，その村性機䅜に関して は不明である，今まで反罚動物において，単離が困難で あるとされていた脂肪細胞をめん羊の脂肪組織より，コ ラケ゚ナーゼ処理にて単離することに成功した。そこで, この単雉脂肪細胞を用いてインスりン受容体に対するイ ンスりン結合の Kinetics を解析することにより，ラッ トのそれと比較し，反别動物に粎けるインスリン抵抗性 の機構の一端を解明した。

めん羊の単離脂肪細胞に対する ${ }^{125} \mathrm{I}$-insulin の特買結 合は $4.82+0.41 \%$ 上ラットのそれの70\%であったな 怙，インスリン結合は $3.9 \times 10^{-11} \mathrm{M}$ から $4.2 \times 10^{-9} \mathrm{M} の$ 生理的濃度籁用でラットに比し有意 $(\mathrm{P}<0.02)$ に低か った negative cooperativity model に徤い. Scatchard plotを解析した結果，めん羊括よびラットの $\bar{K}_{日}$ （受容 体がインスリンによって全く占有されていない時の親和 定数）は，それそれ $1.29 \times 10^{8} \mathrm{M}^{-1} ， 1.76 \times 10^{8} \mathrm{M}^{-1}, \bar{K}_{f}$ （全受容体がインスリンによって占有された時の親和定 数) は $0.50 \times 10^{8} \mathrm{M}^{-1}, 0.67 \times 10^{8} \mathrm{M}^{-1}$ であり， $R_{O}$ (全受 容体数) は $2.32 \times 10^{5}$ sites $/$ cell, $2.56 \times 10^{5}$ sites $/$ cell で あった、さらに, average affinity profile は受容体占有 率 10\% 時での親和力がラットの50\%であることを示し た. 以上の解析結果から，ぬん羊における低インスリン 結合は，受容体数の違いというよりは无しる低親和力に よるものであり、このことが反留動物に括けるインスリ ン抵抗性の一因をなす电の上考无られる。

日畜会赫，57 (6)：503-511，1986 